British \& Irish Botany 3(3): 373-378, 2021

\title{
The typification of the Linnaean name Atriplex maritima (Chenopodiaceae) revisited
}

\author{
Duilio Iamonico \\ Department PDTA, University of Rome Sapienza, 00196 Rome, Italy
}

Corresponding author: d.iamonico@yahoo.it

This pdf constitutes the Version of Record published on $16^{\text {th }}$ September 2021

\begin{abstract}
The typification of the Linnaean name Atriplex maritima is revisited according to the Art. 7.8 (Ex. 10) of ICN. A specimen deposited at BM (barcode

BM001148306), which is part of the Dale collection, is designated as the lectotype superseding the previous proposed neotypification on BM000647540 (Clifford Herbarium). The correct name for this taxon remains $A$. laciniata $\mathrm{L}$. with $A$. maritima accepted as heterotypic synonym.
\end{abstract}

Keywords: Atriplex laciniata; lectotypification; Linnaean name; nomenclature

\section{Introduction}

Atriplex L. (Chenopodiaceae Vent.) is a genus comprising about 260 species, which are distributed in arid and semiarid regions of Eurasia, America, and Australia (Akeroyd, 1993; Sukhorukov \& Danin, 2009; Kadereit et al., 2010; Brignone et al., 2016). According to Kadereit et al. (2010) this genus is monophyletic, including Obione Gaertn., Teutliopsis (Dumort.) Celak., and some other segregate genera.

As part of the ongoing studies of Linnaean names in Amaranthaceae sensu APGIV (2016) (see e.g., Iamonico, 2014, 2016, 2017; Iamonico \& Jarvis, 2012; Iamonico et al., 2012; Iamonico \& Kadereit, 2013; Iamonico \& Sukhorukov, 2014) one, Atriplex maritima L., was recently typified by Iamonico (2020). However, the proposed neotype [the specimen no. 469-Atriplex 3 included in the Clifford Herbarium at $\mathbf{B M}]$ is not correct, and the typification is here revised.

\section{Material and methods}

This research is based on the analysis of relevant literature (i.e. protologues of the names investigated and pre-Linnaean works therein cited, and primary Floras in which the studied names are listed) and examination of specimens preserved at BM (herbarium code following Thiers, 2021 [continuously updated]). The articles cited throughout the text follow the Shenzen Code (Turland et al., 2018). 


\section{Typifications}

Atriplex maritima L., a name published by Linnaeus (1754: 25) in his edition of Flora Anglica, was validated by a mere reference to the species numbered "1528 " in the third edition of Ray's Synopsis Methodica Stirpium Britannicarum (1724: 152-153). Therefore, the typification of this name must be undertaken from the context of Ray's publication, not to the collection of Linnaeus, according to the Art. 7.8 of ICN (Ex. 10) which states: "A name of a new taxon validly published solely by reference to a previously and effectively published description or diagnosis ... is to be typified by an element selected from the entire context of the validating description or diagnosis, unless the validating author has definitely designated a different type ...".

Iamonico (2020), believing that no original material exists, proposed to neotypify the name Atriplex maritima on a specimen preserved at BM (barcode BM000647540; image available at https://www.nhm.ac.uk/resources/researchcuration/projects/clifford-herbarium/lgimages/BM000647540.JPG). However, according to the Art. 7.8 of ICN (Ex 10), Iamonico's neotypification cannot be accepted since original material (Ray's context) is in existence.

First, Ray (1724: 152) reported as synonyms of his "Atriplex maritima" (the species no. 8 in of his treatment) the following three polynomials: "[Atriplex] maritima laciniata" (from Bauhin, 1623: 120), "[Atriplex] marina" (from Gerhard, 1597: 257), and "[Atriplex] marina repens" [from L'Obel (1591: 255) and Parkinson [1640: 748 (not "758" as reported by Ray l.c., probably a typographic error)]. Gerhard (1597), L'Obel (1591), and Parkinson (1640) provided illustrations (images available, respectively, at https://www.biodiversitylibrary.org/item/109874\#page/277/mode/1up, https://www.biodiversitylibrary.org/item/37876\#page/262/mode/1up, and https://www.biodiversitylibrary.org/item/256142\#page/774/mode/1up) which can be considered for the typification of the Linnaean name Atriplex maritima (see Ex. 10 of the Art. 7.8 of ICN).

Furthermore, Ray (1724: 152) indicated the habitat and the provenance ("On the Sea-shore near Little Holland in Essex. Found also by Mr. Dale in the Isla of Mersey, not far from Colchester plentifully"). Material from Mersea is stated by Ray (1724: 152) to have been found by Samuel Dale, whose collections still survive at BM (C. Jarvis pers. comm., but see also HUH Index of botanists, 2013 onwards). I traced one of Dale's specimens (original material) at BM (barcode BM001148306) which is mounted on a sheet (left part) together with a second exsiccatum (barcode BM001148307, right part). An original label, including both a description and the locality of collection ("I have found this plant growing ... on the sandy shores of Mersey Island, near Harwich and other places of Essex") also occurs on the sheet and it is clearly linked with Dale's plant.

Among the elements found (Gerhard's, L'Obel's, and Parkinson's illustrations and BM specimen collected by S. Dale), according to the Art. 9.12 (Ex. 12) of ICN, specimens have precedence over illustrations in lectotype designation. As a consequence, I here designate the specimen BM001148306 as the lectotype of the name Atriplex maritima (Fig. 1). 
Concerning the identity of the Linnaean name Atriplex maritima, BM001148306 is identifiable as $A$. laciniata $\mathrm{L}$. according to the current species concept in the genus (see e.g., Akeroyd, 1993; Welsh, 2003). Moreover, note that the Bauhin's polynomial "maritima laciniata" (Bauhin, 1623), cited by Ray (1724: 152) in his Synopsis, was previously reported by Linnaeus (1753: 1053) as a synonym of Atriplex laciniata L. in the first edition of Species Plantarum, whereas in the second edition of Species Plantarum (Linnaeus, 1762: 1493) the Bauhin's phrase name was again listed as synonym of $A$. laciniata, but the name $A$. maritima was not included. Linnaeus $(1753,1762)$ therefore changed his original concept of $A$. maritima and later included it in $A$. laciniata. Stearn (1973: 64) synonymised the Linnaean $A$. maritima with $A$. laciniata, and I agree with this consideration (see also Iamonico, 2020).

Atriplex laciniata L., Sp. PI. 2: 1053. 1753. - TYPE (lectotype designated by Taschereau, 1972: 1591) Herb. Clifford: 469, Atriplex 3 (BM000647540!). An image of the lectotype is available at

https://www.nhm.ac.uk/resources/research-curation/projects/cliffordherbarium/lgimages/BM000647540.JPG

= Atriplex maritima L., Fl. Angl.: 25. 1754 - TYPE (lectotype designated here): Type: United Kingdom, England, East, Essex, Colchester, Mesrea Island, s.d., Dale s.n. (BM001148306! [plant on the left], designated here; Fig. 1).

\section{Acknowledgements}

Thanks are due to J. Hunnex (Herbarium BM) who sent me an image of Dale's plant (lectotype of Atriplex maritima) and gave the permission to reproduce it, and to C. Jarvis (Natural History Museum, London) for the useful suggestions.

\section{References}

Akeroyd, J.R. 1993. Atriplex L. In: Tutin, T.G., Burges, N.A., Chater, A.O., Edmonson, J.R., Heywood, V.H., Moore, D.M., Valentine, D.H., Walters, S.M. \& Webb, D.A., eds., Flora Europaea, $2^{\text {nd }}$ ed., 1: 115-177. Cambridge: Cambridge University Press.

APGIV 2016. An update of the Angiosperm Phylogeny Group classification for the orders and families of flowering plants: APG IV. Botanical Journal of Linnean Society 181: 1-20.

Bauhin, C. 1623. Pinax theatri botanici. Basileae: sumptibus \& typis Ludovici Regis.

Brignone, N.F., Denham, S.S. \& Pozner, R. 2016. Synopsis of the genus Atriplex (Amaranthaceae, Chenopodioideae) for South America. Australian Systematic Botany 29: 324-357.

Gerhard, J. 1597. The Herball, or, Generall historie of plantes. London: John Norton.

HUH Index of botanists 2013 onwards. Index of botanists, Harward University Herbaria \& Libraries. [accessed 15 March 2021]. Available at: https://kiki.huh.harvard.edu/databases/botanist search.php?mode=details \&id $=47839$ 
Iamonico, D. 2014. Lectotypification of Linnaean names in the genus Achyranthes L. (Amaranthaceae). Taxon 63: 405-407. http://dx.doi.org/10.12705/632.2

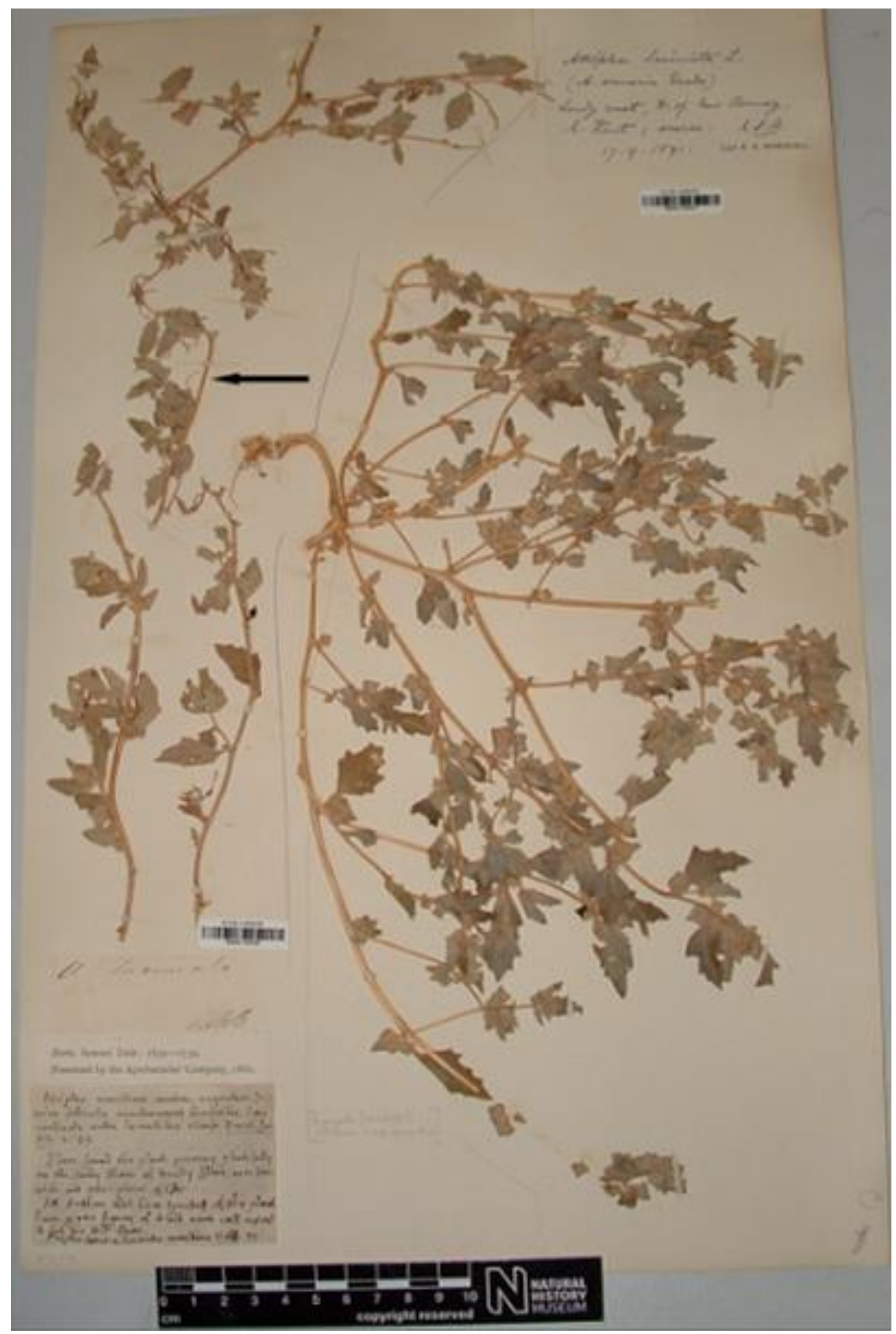

Figure 1. Lectotype of the name Atriplex maritima (BM001148306!). Arrow indicates the lectotype. 
Iamonico, D. 2016. Nomenclature survey of the genus Amaranthus (Amaranthaceae). 3. Names linked to the Italian flora. Plant Biosystems 150(3): 519-531. http://dx.doi.org/10.1080/11263504.2014.987188

Iamonico, D. 2017. Atriplex L. In: Pignatti, S., ed., Flora D'Italia, $2^{\text {nd }}$ ed., 2: 250-256. Bologna: Edagricole.

Iamonico, D. 2020. Typification of two Linnaean names in Atriplex

(Amaranthaceae sensu APG IV) referred to ancient Flora Anglica by Hudson and Linnaeus. British and Irish Botany 2(3): 202-206. https://doi.org/10.33928/bib.2020.02.202

Iamonico, D. \& Jarvis, C.E. 2012. Lectotypification of two Linnaean names in Chenopodium L. (Amaranthaceae). Taxon 61(3): 864-865.

Iamonico, D. \& Kadereit, G. 2013. Typification of the name Kochia saxicola (Chenopodiaceae). Novon 22(4): 418-421. http://dx.doi.org/10.3417/2011058

Iamonico, D. \& Sukhorukov, A.P. 2014. Studies on the genus Atriplex (Chenopodiaceae) in Italy. VI. Names by Michele Tenore: Atriplex axillaris, A. diffusa, and A. polysperma. Hacquetia 13(2): 285-296. 10.2478/hacq2014-0005.

Iamonico, D., Sukhorukov, A.P. \& Jarvis, C.E. 2012. Lectotypification of the Linnaean name Anabasis foliosa L. (Chenopodiaceae). Taxon 61(5): 11031104.

Kadereit, G., Mavrodiev, E.V., Zacharias, E.H. \&, Sukhorukov, A. P. 2010. Molecular phylogeny of Atripliceae (Chenopodioideae, Chenopodiaceae): Implications for systematics, biogeography, flower and fruit evolution, and the origin of C4 photosynthesis. American Journal of Botany 97(10): 1664-1687.

Linnaeus, C. 1753. Species plantarum, 2. Holmiae: Laurentii Salvii.

Linnaeus, C. 1754. Flora Anglica. Upsaliae: Laur. Magnus Hojer, Reg. Acad. Typogr.

Linnaeus, C. 1762. Species Plantarum ed. 2, 1. Stockholmiae: Laurentii Salvii. L'Obel de, M. 1591. Icones Stirpium seu plantarum tam exoticarum, quam indigenarum 1. Antuerpiae: Ex Officina Plantiniana.

Parkinson, J. 1640. Theatrum Botanicum. London: Tho. Cotes.

Ray, J. 1724. Synopsis Methodica Stirpium Britannicarum, $3^{\text {th }}$ ed. Londini: Impensis Gulielmi \& Joannis Innys Regiae Societatis Typographorum.

Stearn, W.T. 1973. Ray, Dillenius, and the Synopsis methodica Stirpium Britannicarum. London: The Ray Society.

Sukhorukov, A.P. \& Danin, A. 2009. Taxonomic notes on Atriplex sect. Teutliopsis and sect. Atriplex in Israel and Syria. Flora Mediterranea 19: $15-23$.

Taschereau, P.M. 1972. Taxonomy and distribution of Atriplex species in Nova Scotia. Canadian Journal of Botany 50: 1571-1594.

Thiers, B. 2021 [continuously updated]. Index Herbariorum: A global directory of public herbaria and associated staff. New York Botanical Garden's Virtual Herbarium. [accessed 15 March 2021]. Available at: $<$ http://sweetgum.nybg.org/ih/>. 
Turland, N.J., Wiersema, J.H., Barrie, F.R., Greuter, W., Hawksworth, D.L., Herendeen, P.S., Knapp, S., Kusber, W.-H., Li, D.-Z., Marhold, K., May, T.W., McNeill, J., Monro, A.M., Prado, J., Price, M.J. \& Smith, G.F. (eds.) 2018. International Code of Nomenclature for algae, fungi, and plants (Shenzhen Code). adopted by the Nineteenth International Botanical Congress, Shenzhen, China, July 2017. Regnum Vegetabile 159: 1-254.

Welsh, S.L. 2003. Atriplex L. In: Flora of North America Editorial Committee (eds.), Flora of North America North of Mexico (Magnoliophyta: Caryophyllidae) 4: 306-307. New York \& Oxford: Oxford University Press.

Copyright retained by author(s). Published by BSBI under the terms of the Creative Commons Attribution 4.0 International Public License.

ISSN: $2632-4970$

https://doi.org/10.33928/bib.2021.03.373 